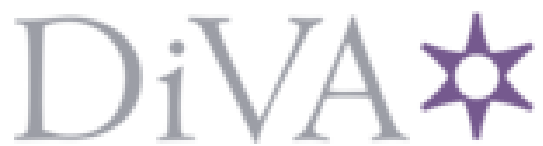

http://www.diva-portal.org

This is the published version of a paper published in Education 3-13.

Citation for the original published paper (version of record):

Rantala, A., Heikkilä, M. (2020)

Agency, guidance and gender: interrelated aspects of early childhood education settings

Education 3-13, 48(4): 483-493

https://doi.org/10.1080/03004279.2019.1620305

Access to the published version may require subscription.

N.B. When citing this work, cite the original published paper.

Permanent link to this version:

http://urn.kb.se/resolve?urn=urn:nbn:se:umu:diva-167939 


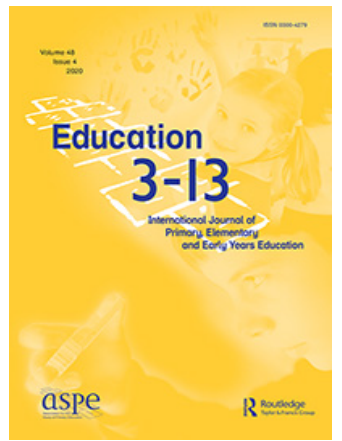

\section{Education 3-13}

International Journal of Primary, Elementary and Early Years Education

ISSN: 0300-4279 (Print) 1475-7575 (Online) Journal homepage: https://www.tandfonline.com/loi/rett20

\section{Agency, guidance and gender - interrelated aspects of early childhood education settings}

\section{Anna Rantala \& Mia Heikkilä}

To cite this article: Anna Rantala \& Mia Heikkilä (2020) Agency, guidance and gender interrelated aspects of early childhood education settings, Education 3-13, 48:4, 483-493, DOI: 10.1080/03004279.2019.1620305

To link to this article: https://doi.org/10.1080/03004279.2019.1620305

\section{9.}

Submit your article to this journal $₫$

Џll Article views: 232

Q View related articles $\asymp$

View Crossmark data $\nearrow$ 


\title{
Agency, guidance and gender - interrelated aspects of early childhood education settings
}

\author{
Anna Rantala ${ }^{\mathrm{a}}$ and Mia Heikkilä (1D ${ }^{\mathrm{b}}$ \\ ${ }^{a}$ Faculty of Applied Educational Sciences, Umeå University, Umeå, Sweden; ${ }^{b}$ Faculty of Education and Welfare \\ Studies, Åbo Akademi University, Vasa, Finland
}

\begin{abstract}
Social interaction is one of the many things what preschool life is about, and how social life is constituted is of importance to understand. In early childhood education settings, children are guided and fostered by teachers and by each other in different directions. The overall aim of the article is to make a contribution to a deeper understanding of how children's agency is performed as a constantly gendered social activity and how this is affected by the guidance they receive from teachers. The relationship between agency, gender and guidance is scrutinised. By using Foucault's concepts discipline and power in combination with understandings of childhood and gender order this is explored. The empirical material consists of ethnographic observations in two preschools, and the results show how agency, gender and guidance need to be understood as relational processes when highlighting aspects of children's social life in ECE.
\end{abstract}

\section{ARTICLE HISTORY}

Received 29 March 2019

Accepted 10 May 2019

\section{KEYWORDS}

Preschool; guidance;

children's agency;

ethnography; gender; early

childhood education

\section{Introduction}

Children's social life in preschool can obviously be conceived and understood in a variety of ways. In social life in preschools, children are guided and fostered by teachers and by each other and guidance is an area that we have noticed risks being taken for granted in early childhood education (ECE).

In several studies, researchers have observed how children are guided, perhaps many times unconsciously, towards homogenisation. They are moulded to adapt according to prevailing norms and desirable behaviours and actions (Dolk 2013; Ekström 2007; Emilson 2008; Jonsson and Williams 2013; Markström 2005; Palla 2011; Rantala 2016). Children are at the same time guided towards becoming independent (Bigsten 2015; Ekström 2007; Markström 2005; Palla 2011), guided towards functioning in a democratic society (Granbom 2011; Markström 2005) and to adapting to collective norm systems by adhering to rules and practices (Ekström 2007; Palla 2011). These studies altogether show that children's scope for agency is limited, but their actions are expected to be normalised in certain directions. At the same time, they are expected to show capacity and competence through active agency. There seems to be an intention to foster children towards the right to be unique, to be active subjects, but also an aspect of guiding children towards prevailing norms, which means that the children instead are guided towards homogenisation (Rantala 2016). This emerging contradictory way of being a child is here argued is a result of how teachers' guidance, gender norms and children's agency are displayed in ECE practice. 
Concerning gender norms, there is research of how preschool teachers have different expectations of children's actions and behaviours based on their gender (see, e.g. Eidevald 2009; Hellman 2010; Karlsson 2009; Markström 2005; Månsson 2000, 2010; Odenbring 2010; Rantala 2016). Eidevald (2009) shows, for example, that teachers unconsciously seem to respond to and judge girls and boys based on discursive assumptions that girls and boys are fundamentally different. He states that this underlies how teachers look at the children's relations and their needs. Preschools can be said to be organisations where gender negotiations take place through the use of communicative modes and multidimensional social positioning, and sometimes these processes and positions are, from a gender point of view, contradictory (Davies 2003; Kress 2003; Paechter 2007).

Research shows how teachers' unconscious gender stereotyping means that both girls and boys receive most help from teachers when they work with such subject areas that are gender-coded so that the children are easily perceived either as feminine or masculine (Renold 2006). Renold also writes that the teachers' unconsciousness about gender can make teachers reinforce gendercoded comments if their interpretation of who a child is, is in line with stereotypical expectations of the child as a girl or boy. For instance, a boy's good results in mathematics can be enhanced or exaggerated by a teacher who is not aware of gender patterns, while a girl's good results in physics can be met with scepticism and perceived as uneminent. Wardman (2017) also describes how the teacher's perceptions of boys' behaviour as related to biological 'facts' means that the boys themselves use it when they are unable or unwilling to sit still, listen or do tasks. In her study, she, in line with other researchers' results (including Robinson 2005), saw that the boys escaped from disciplinary measures since their behaviours 'were' understood as naturally boyish.

Hellman (2010), for instance, further shows how gender norms are related to how children are communicating in a preschool environment. She studies boyhood in relation to preschool activities and sees how boyhood is realised in different ways, and how both children and teachers participate in this 'doing difference'. It clearly affects the children's scope of action that gender is made both by other children and teachers. As a result, Hellman shows that children's scope of action is related to the norms of how a preschool child is expected to behave and be, and how girls and boys are expected to behave and be. Her study shows that it is not possible to only look at children's action in general at preschool without relating it to the gender of the children.

The presented research show that prevalent gender norms are visible in teacher's actions and guidance of children towards homogenisation. Children's way of acting in contexts were such norms are active reinforces such norms. Breaking these expected norms of how to behave risk to affect children's agency. This will be empirically explored in this article.

\section{Aim and research questions}

This article clarifies how adults' guidance of children is performed in relation to prevalent preschool norms as well as gender norms and how this affects both gender patterns and children's agency at the preschool. The overall aim of the article is to contribute to a deeper understanding of how guidance, gender norms and agency are constant interrelated social activities and how this affects children in ECE in relation to gender and agency. The relationship between guidance, gender and agency is scrutinised. This is a re-analysis of everyday situations in two different preschools in which children and adults interact in everyday educational activities (cf. Rantala 2016). The re-analysis is carried out in order to uncover how guidance and agency are performed in preschool, with specific focus on exploring how guidance, agency and gender can be understood in relation to ECE settings.

The research question is:

- How can teachers' guidance, gender norms and children's agency be understood in relation to each other? 


\section{Theoretical perspectives on the relation between the concepts guidance, agency and gender}

Concerning the concept of guidance in preschool, the term used in previous research is often associated with guidance on subject teaching. Guidance is here understood as a way to lead children, and it is here analysed how this is done differently in relation to boys and girls. For example, Carbonneau and Marley (2015) describe instructional guidance in relation to mathematics teaching in preschool. Also, Pollard-Durodola et al. (2012) use the concept of instructional guidance but in relation to reading in preschool. Millei (2011) also uses the term guidance in her article but not in relation to the dissemination of subject knowledge without problematising guidance as a subtle way of regulating children. She uses 'Foucault's conceptualization of power and confession' (88).

In this article, the term 'guidance' is used, not in relation to subject knowledge, but in relation to gender norms, values and children's agency. Foucault's theories on power and discipline are used and explored in the analysis, arguing that processes of power and discipline lead to normalisation in relation to a certain context. Norms can be said to be the result of power distribution in contexts that all people through their actions are a part of (Foucault 1983, 2003).

Power appears when people are agreeing or disagreeing on something and Foucault (2003) also claims that power is productive. The power that appears when people interact, as in situations of guidance between an adult and a child, creates the organising of human systems, or as he calls it, norms of what are considered as normal human acts. These norms differ between time and space and also among groups of individuals. Foucault uses the concepts of discipline in order to deepen the understanding of how the normalisation processes are expressed.

In this article, Foucault's theories of discipline and normalisation are used in order to crystallise situations where teachers in preschool try to change children's behaviour in accordance with norms created in society or in preschool practice. This also includes situations where teachers encourage children to continue with something, from the teacher's perspective, desirable behaviour.

We put a gender perspective on power and, like Francis and Skelton (2001), we see gender as being created in relationships where power is a central aspect. Gender norms are about power and positioning in relation to boys and girls and are created in certain ways in preschools, being a time and space where this can be done. In a preschool environment, power is created and negotiated, for example, in children receiving and taking different speech spaces, different play spaces and different influence over activities, according to the earlier research mentioned. The practice of guidance and how agency is practiced limits and creates arenas for power to be distributed, and thereby gender norms to be created. These aspects are well-documented, and whether there are additional aspects of power relations in preschool is an empirical question.

Power is thus something that surrounds all individuals, and all individuals are co-creators of power. This means that guidance cannot be seen as a linear or isolated activity, rather as a process of constant negotiations in a specific context. Guidance as a process of constant negotiations in a specific context has its limitations and possibilities. Corsaro (2005), for example, brings forward that children are not passive recipients but active agents, who are involved in the design of the context in which they operate, as well as in their own development. According to Corsaro, children acquire 'information and knowledge from the adult world' (41) and through the processing of their peer cultures then can contribute 'to the reproduction and extension of the adult culture' (41). This process Corsaro calls interpretive reproduction, which means seeing a progression not only over time but also in the explicit moment. This can be related to the concepts of guidance and agency that draws attention to how children's influence and space are regulated and manifested. James, Jenks, and Prout (1998) show how children's agency needs to be made visible to give children's voices legitimacy. According to Swedish national preschool curricula, children should have the ability to express and show agency in preschool, however, how this agency is formed is a task for empirical studies to research. Stoecklin and Fattore $(2018,48)$ see agency as 'one's capacity to act', and that it is always made possible and constrained by norms (cf. Mizen and Ofosu-Kusi 2013). In line with Stoecklin and Fattore (2018), 
children's agency is created as multidimensional, and children's agency as being multidimensional is also considered in this analysis.

In this re-analysis, we empirically analyse how agency, gender and guidance are interlinked to each other and how guidance as a social practice in ECE settings is gendered, and at the same time enable children's different agency in a continuum. It is argued in this article that children's agency can never be seen without considering aspects of gender and guidance, and that agency never appears neutrally.

\section{Data construction, methodological and ethical considerations}

This article is based on data from an observation study at two Swedish preschools published in XXX (2016). The data from that large study are here re-examined and re-analysed in terms of deepening understanding of how guidance, gender norms and children's agency are aspects related to each other in social life in preschools. In this re-analysis, a shift of focus is also affected - from a focus on teachers to a focus on children in attempting to grasp a child perspective of guidance.

Two preschools were part of the original study, and data from one of the preschools are re-analysed here. The preschool was located nearby a medium-sized city in Sweden. At that preschool, three units were part of the study: Aspen, Eken and Björken. The units consisted of a total of 50 children, and 47 guardians gave their consent for their children to participate in the study: 22 girls and 25 boys aged 3-5 years. From this preschool, 11 preschool teachers participated. The limitation of this study is the relatively small empirical data, which restricts the possibility to make generalisations of the results. The results can be used when further discussing social life in preschools and what aspects need to be taken into consideration when developing preschool contexts.

The empirical material underlying this article was collected in 2013-2014 and consists of video observations (the entire study consists of $37.5 \mathrm{~h}$ of video film, of which 28 are used as the basis for this article). All situations where children and adults were interacting have been transcribed and initially processed through an inductive thematic analysis (Boyatzis 1998). The inductively generated themes and their content have since been analysed with different theoretical concepts.

All preschool teachers and all the guardians of the children were asked to give informed, written consent. The children whose guardians did not agree on participating in the study were excluded from the observations. Of the 83 children, 73 took part in the study.

Consent has also been obtained from the children, according to the Swedish Research Council (Vetenskapsrådet 2017). This was done by initially introducing the purpose to all the children and giving them the opportunity to give consent or not. The researcher was though continuously observant when children, either verbally or in other ways, expressed that they did not want to be filmed. In these situations, the recording was stopped.

All informants are here made anonymous, mainly by changing their original names. There are also situations where children are described as, for example, calm, silent, caring or outgoing or opposing. This is nothing we claim as essential for the children, but it is something we have experienced when collecting data, and further in the analysis of the video material. These terms we have considered as ways of describing what actions, verbalisations and behaviours are seen in the video sequences.

\section{The re-analysis}

The re-analysis made in this article focuses on how children's gendered agency is realised and how it is shown in relation to the teachers' guidance.

We do not wish the reader to see the children presented only as representatives of themselves, but of types in a certain context possible to find elsewhere. In this article social patterns are seen as related to each other - where agency, guidance and gender are closely linked together. In the results part, we exemplify how these are linked together in how children are seen in the preschool context. 


\section{Results}

The analysis presented focuses on the children that receive a lot of guidance. We have studied how these children's agency is formed according to these patterns. A limitation of the study is that the results focus on children that receive a lot of guidance, a choice made primarily of methodological reasons. It is harder to empirically analyse lack of guidance. It does not mean it being unsignificant. In cases of lack of guidance that were observed, we can only see tendencies according to the children's way of acting, and these analyses have thereby a lower reliability. One of the authors have conducted the empirical study and has observation notes as support for these understandings.

In the analysis, we have included an analysis of what gender norms are activated as part of the guidance. The reason for focusing on children receiving a lot of guidance is since it is possible to contrast and discuss guidance, agency and gender norms according to the research questions presented. The sequences of social interaction that were analysed makes it possible to discuss what occurs concerning these three related aspects of social life in this context, and also formulate what it means.

In the following examples, a number of boys' and girls' agencies will be described and analysed, in relation to the guidance their actions and behaviours give rise to. The focus of the examples we present is to exemplify how a child's agency is limited in various ways by guidance, and how it is done different depending on the gender of the children. The overall aspect of all these analyses is, in accordance with Foucault, how power is distributed between the participants in the context, and how the power distribution affects the participants' possibilities to act and speak.

\section{Emil and Jesper - calm, cautious boys get lots of guidance}

In three out of four groups studied here, boys who were experienced as calm and cautious got a lot of guidance. It is here represented here by Emil (3 years) from the Eken unit and Jesper (3 years) from the Björken unit. These boys are representatives of a type of child that was found in all groups of children but is represented here by Emil and Jesper.

Emil was a child who was very calm and cautious but still received much guidance. One example of this is when all the children in the unit would dress to go out. Emil stands still on the side watching the other children. While the teachers help the other children, they try to guide Emil to be active. At one point, the teacher Pernilla says: 'Then you get dressed Emil'. Another time, teacher Patricia says: 'Here Emil, now l've put your pants on the floor and you just need to crawl into them. The pants first'.

Emil also receives guidance during circle time. The teacher's guide Emil to sit on the round carpet while other children do not get the same guidance: for example, Elliot, who stays on a sofa and picks up a game. During another documented circle time in this unit, Emil also receives guidance. The activity they perform during the circle time is that they clap their hands, as many times as vowels in their name, while pronouncing a child's name. When it is Emil's turn, teacher Patricia says 'Emil', as she claps twice (where the vowels are heard): 'Em-il'. Emil does not react. He seems to be deep into his own thoughts. Patricia says: 'But you must listen to your name!' It required some from the teachers to get Emil to act as the teachers seemed to be a desirable action. Emil then changed his behaviour in accordance with the teachers' guidance.

Jesper is from the Björken preschool unit. He was also experienced as a child who usually acts calmly and cautiously. An example of when Jesper receives guidance is when he stands to paint at an easel. Instead of starting painting on the paper that is attached to the staff, he uses his brush, spins it around in the watercolour, and then puts it in the bowl of water. There he finds that the water changes colour when he leaves the brush in it. He says: 'I am mixing and making some different colors'. When teacher Patricia passes, she guides Jesper to a certain action. She says: 'Will you start painting now?' Whereupon Jesper answers: 'I am just mixing all the colors'. Patricia confirms Jesper by saying: 'You did that', then she guides him again by saying: 'Will you start painting here now?' She points to the paper with her finger. Jesper seems not to act in the way he is expected according to the teacher. Jesper continues mixes the colours in the water until the teacher has given 
him guidance a few times. Then he begins to paint on the paper and the educator seems satisfied and does not continue with the guidance.

The difference between Emil's and Jesper's actions was that Jesper could be perceived as outgoing on a few occasions. However, this was just a few times, which meant that he still got a lot of guidance in situations where he did not act so.

The similarity between Emil's and Jesper's actions was that they both relatively quickly restricted their agency by adapting their actions towards the guidance they received from the teachers, which differs from Adrian's conduct, which will be presented below.

\section{Adrian - making resistance also means getting a lot of guidance}

The boy at the Aspen unit who got the most guidance was Adrian (4 years). He was a boy who was perceived as extrovert and intense in the eyes (and verbalisations) of the teachers, but also according to other children's perception. He was the child that many children blamed (in situations where their own actions were questioned by the teachers), even though he would not even be present. Adrian can here represent this group of boys who were perceived as extrovert, active and intense, which meant that they received a lot of guidance.

As for Adrian, one of the teachers was often close to him. He received a lot of guidance in many different situations and sometimes he was also excluded from the rest of the group by being brought to another room by a teacher or that he goes away himself and a teacher follows. One example of the latter is when the Eken unit was about cleaning up toys. Adrian is inside the unit's smallest room and stands on a sink when the teacher Pia enters the room and tries to make him start cleaning. Pia says: 'Do you want to take up these things, Adrian?' She bends down for some things and continues the guidance by saying: 'Do you know this is so fragile. Do you know where to put it? Do you know what it's for?' Adrian says: 'Bye bye!' He walks out of the room and closes the door. Pia follows him and closes the door. When the door opens and the documentation goes on, Pia sits in the hall with Adrian on her knee. Adrian tries to get off Pia's knee, but Pia holds him tight. After a little while, he begins to bite his own hands, but Pia holds them so he cannot bite them. Throughout the event, Pia talks calmly with him explaining that she does not want him to hurt himself. She gives him a suggestion of things he can do but Adrian says he does not want to. The situation continues in the same style until Adrian seems calm and biddable; he talks calmly about the same thing as the teacher and has stopped saying that he does not want to.

In this situation, his resistance to adult guidance on following rules and procedures (in this case the routine that everyone should clean) was considered problematic, but there were also other children who left the room without carrying out this activity, and these children were not treated in a manner similar to Adrian.

A difference between boys like Adrian and boys like Emil and Jesper was that Adrian did not adapt quickly to the guidance of the teachers. The teachers thus had to 'fight' more to make Adrian conform to current standards and desirable behaviour in comparison with other children. He struggled to claim his right to his agency by arguing that he did not want to or did not respond to the attempts of the teacher for guidance, which in turn led to more guidance from the teachers until he had conformed. This way of using his agency, to argue visibly, was made by girls who received a lot of guidance, and this will be described next.

\section{Josefina and Kelly - argue and resist and get a lot of guidance}

The girls who received the most guidance in all three groups were girls who argued and put up a lot of resistance. Something that became visible in the result was that the girls' ways of arguing differed. Representatives of these different ways of arguing are Kelly ( 3 years) who is at the Eken unit, and Josefina (5 years) who is at the Björken unit. 
Kelly ( 3 years) was often experienced to resist and argue, which resulted in that she received a lot of guidance. She expressed determination and knew what she wanted to do. In one situation, the teacher Petra is sitting on the floor together with Kelly and Edvin (4 years). They are sitting and working on a material with screws and screw-nuts. The material also includes several papers with drawings of things that they can build. Kelly, who is watching a paper drawing, says that 'we will do that', while pointing at one of the drawings. Petra tries to guide Kelly against wanting to build something else. She states that Kelly finds such difficult things to build. Kelly continues to argue by saying they will build just that figure on the drawing that she has found. Petra continues trying to guide Kelly in another direction by asking if there is some easier stuff to build. She picks up another drawing and says, 'This [is] maybe a little easier'. She lifts one of the other drawings and says, 'Oh, a crane, it was cool too. But it looked hard'. She takes up another drawing and says that the can built a scale that they can weigh things with. Then she turns to Edvin, who has begun to show interest in the scale and they together decide that that is what they are going to build. In the above situation, Kelly tries to determine in an authoritative way, but she does not get what she wants without the teacher guiding her (albeit perhaps not so clearly) in another direction.

Kelly also has another way of trying to argue. In some situations where she wants to get her way, she can, sometimes crying, claim that she wants to do in a certain way. An example of this is when Kelly is sitting on the floor next to Kasper ( 3 years) and Kurt ( 3 years). Kasper and Kurt sit and build using a magnetic material (squares and triangles that are magnetic and can be attached together). Kelly sits up and takes some magnets from Kurt who then screams: 'No!' Kelly says: 'I have them now', then Kurt says: 'No, I have them'. The teacher Patricia arrives and says to Kelly: 'But you, you know something my friend. He [Kurt] was building with that'. She takes the magnets that Kelly has taken and gives them back to Kurt. Kelly argues by saying: 'Yes, but I want them too'. Patricia continues to guide Kelly by first saying that she can sit next to the boys and maybe help them. Then she also shows Kelly some other magnets that are available and says she can play with them.

In comparison with Kelly, who often argues based on her own perspective - what she wants, or how she wants it, Josefina (5 years) argues instead by claiming her rights. In comparison with most of the children who participated in the study, Josefina stood out in this regard. She seemed to be very aware of the preschool's rules and routines. One example is when Josefina argues by claiming her right is during a circle time. Josefina lay done on the floor on her stomach, while the teachers try to get her to sit up. She resists by saying: 'I have the right to lay done here'. The teacher Paulina continues to encourage her to get up. After a lot of guidance from the teacher, she finally acts as the teacher wants and sets herself up.

Josefina also makes resistance by arguing with the help of the teacher's guidance. An example is when the unit has circle time. Josefina, along with other children, receive guidance's about moving themselves so that the other children also could see what the teacher is doing. In this situation, she moves much more than she needs to and says: 'Do we have to go back, or?' The teacher Paulina says: 'No, not really as far as that', and Josefina says: 'But you said we must move backwards'. The teacher only says: 'Yes', but then another child enters the unit and Paulina turns to this child.

Although these two girls try to claim agency by arguing and resisting in different ways, they receive a lot of guidance. They seem are perceived as girls who do not adapt to the guidance of the teachers, resulting in the guidance continuing until they eventually adapt.

\section{Siri - concentrated and receives a lot of guidance}

The girls who received much guidance were also those who appeared to be highly concentrated in different activities. Here, this group is represented by Siri (4 years) who went to the Aspen unit.

Siri was very concentrated on what she did, which resulted in that she received a lot of guidance. An example is when the department has circle time and Siri is sitting and reading a book. The teacher Pauline tells her to come close and put the book away, but Siri does not respond to the guidance. Pauline goes on and says: Siri, put the book back since we'll hear something here. However, Siri 
continues to browse the book and Pauline continues with her guidance. She says Siri, Siri, Siri, I'm talking to you now. Now you need to put the book down. Now there's something else that is happening. Then Siri returns the book to its place while also looking bored.

Another example of this expectation of breaking their concentration is then when Aspen unit has circle time. The teachers try to get the children to leave their activities and gather in the area where they usually have the circle time. Pauline goes over to Siri and Sander, who are sitting and playing. She grabs Siri to get her on her feet and steering her against the place of the circle time. On the other hand, she does not do the same with Sander, to whom she only says something as she walks to the place where they hold the collection and lets Sander continue with her play.

In comparison with Kelly and Josefina, who tried to argue for their cause, Siri did not say much. Neither does she listen to the teachers' guidance nor tries she to continue with her activities as long as possible. When the teachers have given enough guidance or when they physically try to get Siri to do what they want, Siri accepts the guidance. Although the children are sometimes advised to be focused and focus on what they are dealing with, Siri is expected to break her concentration when she is expected to act in a different way, which leads to her getting a lot of guidance.

\section{Gender analysis of guidance sequences presented}

In the various situations observed (free play, before and during circle time, dressing and tidying up), a child's gendered agency is generally influenced by how the guidance was expressed. Teachers guide girls and boys depending on the type of behaviour they show. It is though not possible, based on the analyses in this article, to say that all boys are guided in a certain way and all girls in another, but it is possible to say that groups of girls showing certain behaviours are guided in a certain way and other groups of girls showing another behaviour are guided in a different way, in different preschool contexts. Groups of boys showing a certain behaviour are guided in a certain way and other groups of boys with other behaviours are also guided differently. This can perhaps be seen as a trivial result, but it shows that aspects of gender norms are active in processes of guidance and agency and how it appears remains an empirical question. This means that gender analyses need to be supplemented with an understanding of how children are influenced by the institution they are in, i.e. preschool, and the gender norms in that context, and children respond to and handle norms they are faced by differently. But what the analyses show is that the behaviour of groups of girls and groups of boys means different guidance by teachers, and that this, in turn, relates to children's agency. Here we argue that it is an empirical question what gender norms are negotiated as relevant in preschool.

In two out of three preschool units studied here, there is a girl who gets the most guidance from the teachers, while in one group it is a boy (XXX 2016). Generally, the boys are given most guidance in connection with play activities when the children themselves decided what they wanted to play. The girls, on the other hand, get the most guidance when it comes to situations where the children are expected to clean and tidy up.

The content of the guidance does not differ very much between gender but it appears on different occasions. For example, boys and girls are guided to perform different things, as well as guided to move or to stay in a certain place. Gender norms appear in guidance on what the children should not do. This guidance is mostly aimed at boys, which can be interpreted as limiting more boys' agency at a general level.

Gender analysis in relation to guidance cannot be limited to children's gender only, but needs to be deepened in relation to actions and behaviours that lead the children to be guided: thus, what actions and behaviours cause a girl to be guided, and what actions and behaviours make a boy guided in preschools. The term agency is set here in relation to the social norms concerning gender and gender manifested through the guidance of the staff.

There is a difference between how the boys and the girls who receive very little guidance act. Among the boys were those who were seen and heard, but not too much. It can be described that these boys act as an intermediary group between those who feel calm and cautious (who 
receive much guidance), as well as those who argue and make resistance (who also receive guidance). Among the girls who almost not received any guidance, in comparison with the boys, were those who felt calm and cautious which took the lead. The children who are not attracted to almost no guidance can be said to have more opportunity for agency than other children even though they try. Having the opportunity to practice the agency can also apply to those who act in accordance with what seems to be desirable behaviour from the teachers' perspective and are guided by praise and encouragement. However, if the children exercise agency or if they just want to obey the teachers, this study, which the results is based, can't determine.

\section{Conclusion}

The guidance of children is a negotiated and continuously processed activity and can be said to be discussed as related to children's agency and also the gender of the child - These three aspects: guidance, agency and gender, is in practice highly related to each other. This means that, as we have argued, guidance, agency and gender need to be seen in relation to each other and in relation to the context where it appears, and together the conditions for how social relations are realised in the preschool are created.

Guidance towards current norms and desirable behaviours and actions are actively done by the teachers, which is in line with previous research (Dolk 2013; Ekström 2007; Emilson 2008; Jonsson and Williams 2013; Markström 2005; Palla 2011; XXX 2016). In the analysed sequences, the guidance is a form of negotiation of power - 'who gets to decide' - and the negotiation carry some characteristics of resistance to the suggested power order. On the other hand, the results also show that different groups of girls and groups of boys act differently when they encounter the guidance. Some children adapt to the guidance of the teachers while other children challenge it and try to create a greater scope for action than the teachers apparently provide. This suggests that some children have experience and prerequisites to believe that they can affect adults and/or see the possibility of challenging preschool rules and procedures. Other children who adapt more quickly based on the teacher's guidance, may be more insecure in relation to adults' suggestions of what to do in certain situations. When children show resistance teachers might continue with the guidance and, in turn, thus affect the children's agency regarding how the guidance is expressed (see Figure 1).

In addition to the relationship between guidance and agency, the results show that the gender norms are placed in between guidance and children's agency (see Figure 1). In the guidance by the teachers, this is illustrated by how the guidance is expressed in terms of girls and boys in different ways.

The results show that boys who are experienced as 'calm and cautious' get lots of guidance. It shows that boys are expected to be more active than girls, which also has consequences for both boys' and girls' agencies. The norm thus ensures that girls are expected to take a calm and cautious
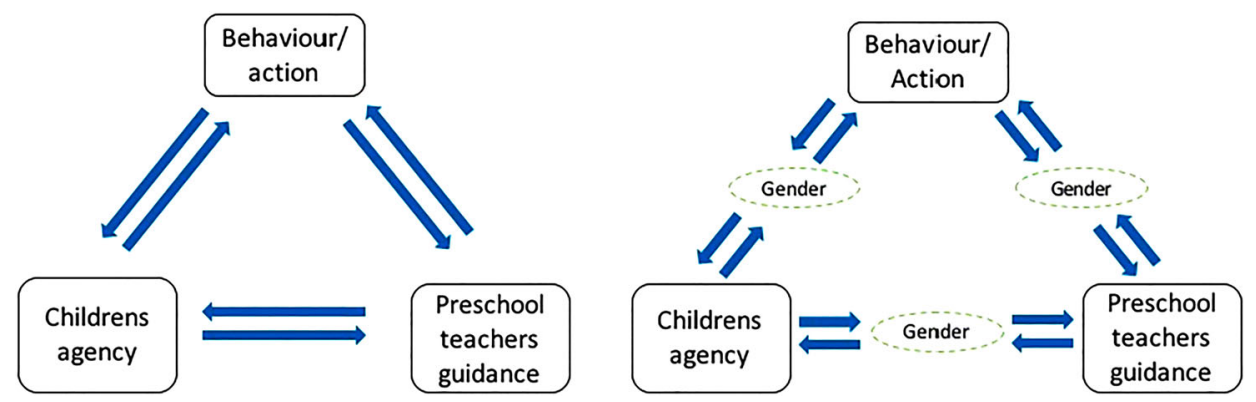

Figure 1. Different processes of agency, gender and guidance in relation to each other. 
role, which can be interpreted as a passive position, while the boys are expected to take a more active position instead, but not to be too active, to argue too much or put up too much resistance.

The fact that norms direct the teachers' guidance instead of giving the children agency to discuss and negotiate norms, creates a certain power distribution between adults and children, whether they are guided towards being more active or not. This means that children risk being deprived of the possibility of being an active subject. The children are positioned as in need of correction in the direction towards current norms in preschool and society, and normalisation in relation to these norms instead of seeing children's different positioning as a force in which they challenge the prevailing norms and structures (cf. Hellman 2010; Odenbring 2010).

In summary, this article exemplifies how gender norms affect adult's guidance of children and also how this affects children's possibilities to exercise and experience agency. This article thus highlights the importance for teachers in preschools to adopt a gender-aware perspective on their guidance to give children possibilities for a variety of positions of agency.

\section{Disclosure statement}

No potential conflict of interest was reported by the authors.

\section{ORCID}

Mia Heikkilä (D) http://orcid.org/0000-0003-3361-348X

\section{References}

Bigsten, A. 2015. Fostran i förskolan. Göteborg: Göteborgs universitet.

Boyatzis, R. E. 1998. Transforming Qualitative Information: Thematic Analysis and Code Development. London: Sage.

Carbonneau, K. J., and S. C. Marley. 2015. "Instructional Guidance and Realism of Manipulatives Influence Preschool Children's Mathematics Learning." Journal of Experimental Education 83 (4): 495-513.

Corsaro, W. A. 2005. The Sociology of Childhood. Thousand Oaks: Sage.

Davies, B. 2003. Frogs and Snails and Feminist Tales: Preschool Children and Gender. NJ: Hampton Press.

Dolk, K. 2013. Bångstyriga barn: Makt, normer och delaktighet i förskolan. Stockholm: Stolkholms universitet.

Eidevald, C. 2009. Det finns inga tjejbestämmare - Att förstå kön som position i förskolans vardagsrutiner och lek. Jönköping: Jönköpings universitet.

Ekström, K. 2007. Förskolans pedagogiska praktik: Ett verksamhetsperspektiv. Umeå: Umeå universitet.

Emilson, A. 2008. Det önskvärda barnet. Fostran uttryckt i vardagliga kommunikationshandlingar mellan lärare och barn $i$ förskolan. Göteborg: Göteborgs universitet.

Foucault, M. 1983. "The Subject and Power." In Michel Foucault: Beyond Structuralism and Hermeneutics, edited by I. H. L. Dreyfus and P. Rabinow, 208-226. Chicago: The University of Chicago Press.

Foucault, M. 2003. Övervakning och straff - fängelsets födelse. Vol. 4e. Translated and edited by C. G. Bjurström. Arkiv förlag: Lund.

Francis, B., and C. Skelton (red.). 2001. Investigating Gender: Contemporary Perspectives in Education. Buckingham: Open University Press.

Granbom, I. 2011. 'Vi har nästan blivit för bra': lärares sociala representationer av förskolan som pedagogisk praktik. Jönköping: Jönköpings universitet.

Hellman, A. 2010. Kan Batman vara rosa? Förhandlingar om pojkighet och normalitet på en förskola. Göteborg: Göteborgs universitet.

James, A., C. Jenks, and A. Prout. 1998. Theorizing Childhood. Cambridge: Polity Press.

Jonsson, A., and P. Williams. 2013. "Communication with Young Children in Preschool: The Complex Matter of a Child Perspective." Early Child Development and Care 183 (5): 589-604.

Karlsson, R. 2009. Demokratiska värden i förskolebarns vardag. Göteborg: Göteborgs universitet.

Kress, G. 2003. Literacy in the New Media Age. London: Routledge.

Månsson, A. 2000. Möten som formar: Interaktionsmönster på förskola mellan pedagoger och de yngsta barnen i ett genusperspektiv. Malmö: Lunds universitet.

Månsson, A. 2010. "Genuspositioner i förskolan - barns möjligheter och begränsningar." In Från storslagna visioner till professionell bedömning - Om barndom, utbildning och styrning, edited by J. Qvarsebo and I. Tallberg Broman, 148160. Malmö: Malmö högskola. 
Markström, A. 2005. Förskolan som normaliseringspraktik : En etnografisk studie. Linköping: Linköpings universitet.

Millei, Z. 2011. "Thinking Differently about Guidance: Power, Children's Autonomy and Democratic Environments." Journal of Early Childhood Research 10 (1): 88-99.

Mizen, P., and Y. Ofosu-Kusi. 2013. "Agency as Vulnerability: Accounting for Children's Movement to Streets of Accra." The Sociological Review 61: 363-382.

Odenbring, Y. 2010. Kramar, kategoriseringar och hjälpfröknar: könskonstruktioner i interaktion i förskola, förskoleklass och skolår ett. Göteborg: Göteborgs universitet.

Paechter, C. 2007. Being Boys, Being Girls: Learning Masculinities and Femininities. Maidenhead: Open University Press.

Palla, L. 2011. Med blicken på barnet: om olikheter inom förskolan som diskursiv praktik. Malmö: Malmö högskola.

Pollard-Durodola, Sharolyn D., Jorge E. González, Deborah C. Simmons, Aaron B. Taylor, Matthew J. Davis, Leslie Simmons, and Miranda Nava-Walichowski. 2012. "An Examination of Preschool Teachers' Shared Book Reading Practices in Spanish: Before and After Instructional Guidance." Bilingual Research Journal 35 (1): 5-31.

Rantala, Anna. 2016. "Snälla du! Kan du sätta dig?: om vägledning i förskolan." Dissertation, Umeå University, Umeå.

Renold, E. 2006. “'They Won't Let Us Play ... Unless You're Going out with One of Them': Girls, Boys and Butler's 'Heterosexual Matrix' in the Primary Years." British Journal of Sociology of Education 27 (4): 489-509. doi:10.1080/ 01425690600803111.

Robinson, K. H. 2005. "Reinforcing Hegemonic Masculinities Through Sexual Harassment: Issues of Identity, Power and Popularity in Secondary Schools." Gender and Education 17: 19-37.

Stoecklin, D., and T. Fattore. 2018. "Children's Multidimensional Agency: Insights into the Structuration of Choice." Childhood 25 (1): 47-62.

Vetenskapsrådet. 2017. Research Ethics and Artistic Freedom in Artistic Research. Stockholm: Swedish Research Council.

Wardman, N. P. 2017. "'So You Can't Blame Us Then?': Gendered Discourses of Masculine Irresponsibility as Biologically Determined and Peer-Pressured in Upper-Primary School Contexts." Gender and Education 29 (6): 796-812. doi:10. 1080/09540253.2016.1166178. 